\title{
EXPERIMENTAL INVESTIGATION ON ELECTRICAL PROPERTIES AND WEAR RATE OF ALUMINUM MATRIX NANOCOMPOSITE (AMNC) OF AA7100/Al ${ }_{2} \mathrm{O}_{3}$
}

\author{
Athraa S. Hasan ${ }^{1}$, Manal K. Oudah ${ }^{2}$, Sahar R. Faraj ${ }^{3}$ Hussain J.M.Al-Alkawi $^{4}$ \\ 150149@uotechnology.edu.iq 250030@uotechnology.edu.iq \\ ${ }^{3}$ 50074@uotechnology.edu.iq ${ }^{4}$ Alalkawi2012@yahoo.com
}

Electromechanical Eng. Dep. / University of Technology/ Baghdad- Iraq

\begin{abstract}
In this study $\mathrm{AA} 7100 / 6 \mathrm{wt} \% \mathrm{Al}_{2} \mathrm{O}_{3}$ metal matrix composite (AMMS) was successfully manufactured using stir casting route. The influence of $6 \mathrm{wt} \% \mathrm{Al}_{2} \mathrm{O}_{3}$ content on microstructure, electrical properties and wear resistance were investigated. The microstructure of composite revealed that homogeneity of $\mathrm{Al}_{2} \mathrm{O}_{3}$ particles in the matrix and also the reinforcement of grains compared to matrix grains. The homogeneity and reinforcement can be attributed to enhance the electrical and wear properties and this perhaps could due to efficiency of stirring process during the casting. The $6 \mathrm{wt} \% \mathrm{Al}_{2} \mathrm{O}_{3}$ content shifted the conductivity and permittivity from reducing in matrix to increasing in the composite when the frequency increased. The wear resistance was improved due to addition of $6 \mathrm{wt} \% \mathrm{Al}_{2} \mathrm{O}_{3}$ compared to matrix.
\end{abstract}

Keywords: Metal matrix, Nanocomposite, Nano-reinforcements.

\section{INTRODUCTION}

The Nano reinforced materials have played an important role for enhancement the electrical and tribological properties of the alloys. Aluminum matrix Nano composites are usually shown good properties when adding the Nano reinforced materials like $\mathrm{Al}_{2} \mathrm{O}_{3}$ ceramic particles. The uniform distribution of the nanomaterial leads to improve the mechanical, electrical and tribological properties like ,tensile strength , hardness , conductivity, magnetic properties (magnetization $(\mathrm{M})$ and field $(\mathrm{H})$ ) , wear rate and coefficient of friction (Ferreira et al 2016, Nalluswamy and Karthikeyan 2016). Electrical conductivity of cadmium oxide $(\mathrm{CdO})$ nanocomposites has been investigated at room temperature (RT) .The nanocomposites were fabricated using sol-gel method poly aniline. Increasing the $\mathrm{CdO}$ content resulted in increase of electrical conductivity (Subhash et al 2011). (AlalKawi et al 2018) fabricated hybrid nanocomposites by adding various amount of iron oxide $\left(\mathrm{Fe}_{2} \mathrm{O}_{3}\right)$ with 
constant weight percentage of alumina $\left(\mathrm{Al}_{2} \mathrm{O}_{3}\right)$ using $\mathrm{P} / \mathrm{M}$ route. They concluded that the composite containing $1.5 \% \mathrm{Fe}_{2} \mathrm{O}_{3}+2 \% \mathrm{Al}_{2} \mathrm{O}_{3}$ showed better response of electrical, magnetic and wear properties. Conductivity and resistivity were measured experimentally by Agilent 4338b milliohm meter for aluminum matrix composites ( $\mathrm{AL}-\mathrm{Zn}-\mathrm{Si}$ ) reinforced with 10, 20 and $30 \mathrm{wt} \% \mathrm{Fe}_{3} \mathrm{O}_{4}$. The above composites were referred to as AF10, AF 20 and AF30 and the conductivity with resistivity were compared with pure aluminum and AL $\mathrm{Zn}$ SI without $\mathrm{Fe}_{3} \mathrm{O}_{4}$. The results indicated that the better composites is AF10 which showed $4996(\mathrm{~S} / \mathrm{m})$ and 0.000281 (ohm-m) as electrical conductivity and resistivity respectively (Ferreira et al 2018) . (Farah et al 2011) studied the alternating current (A.C) Conductivity and dielectric properties of epoxy $-\mathrm{TiO}_{2}$ Nanocomposites. The grain sizes of titanium dioxide $\left(\mathrm{TiO}_{2}\right)$ were $1.5 \mu \mathrm{m}$ and $50 \mathrm{~nm}$ as a reinforced material. They concluded that the relative permittivity parameters reduced when the frequency increased and the A.C Conductivity increased with increasing the frequency and temperature for all composites.(IsIaK et al 2014) investigated the electrical conductivity of $\mathrm{Cu}-10 \% \mathrm{TiC}$ composites with sintering time of 4 minutes at 600, 700 and $800^{\circ} \mathrm{C}$ sintering temperature. They obtained that the ultimate value of electrical conductivity was happened at $800 \mathrm{C}$ with approximately $68.1 \%$ IACS. Two Nano composites, namely AA2024 $-\mathrm{Al}_{2} \mathrm{O}_{3}$ andAA2024- $\mathrm{ZrO}$ were prepared by stir costing route and tested to obtain the electrical conductivity. It was found that the electrical conductivity was slightly enhanced when increasing the content of Nano reinforced for both composites (ALalkawi et al 2018). Wear rate was tested under standard Pin-On-Disc wear tester using Al 6061 / SiC/ $\mathrm{Zr}$ Nano composites fabricated by stir casting technique. It was found that wear resistance was improved significantly due to good dispersion of Nano material in the base metal (Rajasckhar \& Hariprosada 2017). (Ramachandra et al 2015) manufactured $A L / \mathrm{ZrO}_{2}$ nano composites using powder metallurgy method. They examined the wear resistance of the above composites and they observed that wear rates are less when compared to metal matrix indicating improves in wear resistance with increasing in $\mathrm{ZrO}_{2}$ content. In this work, AA7100 / 6 wt $\% \mathrm{Al}_{2} \mathrm{O}_{3}$ nanocomposite was produced by stir casting process. The electrical properties (conductivity) dielectric properties, microstructure, and wear resistance were characterized at room temperature (RT).

\section{EXPERIMENTAL STUDY}

Nanocomposite was fabricated using liquid state technique or stir casting method with 6 wt $\%$ $\left(\mathrm{Al}_{2} \mathrm{O}_{3}\right)$. AA7100 was used as the metal matrix material and aluminum oxide (alumina) $\mathrm{Al}_{2} \mathrm{O}_{3}$ as a reinforced material. Alumina weight percentage is held constant ( $6 \%$ by weight) with average particle size of 20-30 nm. AA7100 Aluminum alloy has good machinability and exhibits good resistance to corrosion under different conditions. Also this alloy is available in different shaped. The chemical composition of the base metal AA7100 is given in table (1).

The mechanical properties of base metal can be seen in table (2) with the mechanical properties of reinforced material $\mathrm{Al}_{2} \mathrm{O}_{3}$

\section{Manufacturing of Composite}

AA7100 $/ 6 \mathrm{wt} \% \mathrm{Al}_{2} \mathrm{O}_{3}$ composite was prepared using stir casting route. Metal matrix was heated to and melted in crucible at $800{ }^{\circ} \mathrm{C}$ reinforcement was preheated to $\left(200^{\circ} \mathrm{C}\right)$ and added one by one slowly during continues stirring speed. The speed of stirring process was (450 rpm) and stirring duration of $(4 \mathrm{~min})$ is maintained. The melt poured into a special mould and the final stage is a rod with $(15 \mathrm{~mm})$ diameter and length $(150 \mathrm{~mm})$ has been produced.

\section{Electrical conductivity and microstructure specimens}

The test sample of electrical conductivity and microstructure is the same and it has $5 \mathrm{~mm}$ in diameter and $2 \mathrm{~mm}$ in length. 
Electrical conductivity was measured for both base metal and nanocomposite $\left(6 \mathrm{wt} \% \mathrm{Al}_{2} \mathrm{O}_{3}\right.$ ) using the LCR-8110G/ $8105 \mathrm{G}$ tester working with large frequency (50 HZ- 50MHZ). This device is able to measure and record the phase angle, inductance, AC resistance, impedance, capacitance, quality factor and conductor. the electrical conductivity of base metal and composite are measured according to standard specification of four wire method.

\section{Wear test}

Pin - on- disc wear testing device was employed for wear rate, weight loss, and coefficient of friction (COF). The experimental data are obtained according to ASTM standard G99.

The following parameters were conducted for the above test:

- $\quad$ Speed $=1.57 \mathrm{~m} / \mathrm{sec}$ on $\mathrm{rpm}$ of 300

- $\quad$ Load $=20 \mathrm{~N}$

- Track distance $=50 \mathrm{~mm}$ (radius)

The sample was run for 10 minutes on the Pin- on disc device. Results are taken for every 10 min interval. Sample dimensions are $10 \mathrm{~mm}$ diameter and $40 \mathrm{~mm}$ length.The pin on disc wear setup is shown in figure (1). The pins were cleaned by using acetone and weighed to an electronic digital weight balance of accuracy $\mp 0.0002 \mathrm{gm}$. The wear rate and volumetric losses were calculated from the wear tested specimens.

\section{RESULTS AND DISCUSSION}

\section{Evaluation Of Microstructure:}

Figures (2) and (3) show the microstructure results of base metal AA7100 and (AA7100 / 6 wt $\% \mathrm{Al}_{2} \mathrm{O}_{3}$ ) nanocomposite .According to microstructure results shown in figures (2) and (3), it can be observed that addition of nano particles of $\mathrm{Al}_{2} \mathrm{O}_{3}$ leads to the obvious dendrite refinement of the base metal. The measurement of dendrite size was carried out using image analyzer software. Figure (4) illustrates comparison between the average dendrite size of the matrix (AA7100) and the composite (AA7100/6wt $\left.\% \mathrm{Al}_{2} \mathrm{O}_{3}\right)$. It is noted that the mean dendrite size reduce from $(172 \mu \mathrm{m})$ to $(77 \mu \mathrm{m})$ for $\mathrm{Al}-$ alloy and $\left(6 \mathrm{wt} \% \mathrm{Al}_{2} \mathrm{O}_{3}\right)$ composite respectively. The dendrite size of composite of $\left(6 \mathrm{wt} \% \mathrm{Al}_{2} \mathrm{O}_{3}\right)$ is decreased by $123 \%$ compared to matrix. Also the results of the microstructure study observed a uniform distribution of $\mathrm{Al}_{2} \mathrm{O}_{3}$ particles in the matrix. The enhancement of electrical and wear properties was mainly due to dendrite refinement and could be mainly attributed to improvement the mechanical and electrical properties. Nano alumina reinforced material which are very small in size, cover the AA7100 resulting in good bounding and don't initial cavities and give rise to grain refinement leads to reduce the dendrite size. Large size of dendrite resulting in weaker strength and some porosity can be generated. Strengthening nanocomposite is due to the dislocation movement by the nano particles (Dinesh et al 2015). (Chen \& Yan 2015) investigated the microstructure properties of $7075 / \mathrm{Al}_{2} \mathrm{O}_{3}$ composite with various amount of $\mathrm{Al}_{2} \mathrm{O}_{3}$. They observed that the average dendrite size decrease gradually from 317 to $60 \mu \mathrm{m}$ for zeronano and $1.5 \mathrm{wt} \% \mathrm{Al}_{2} \mathrm{O}_{3}$ respectively.Also figure (3) reveals good distribution of $\mathrm{Al}_{2} \mathrm{O}_{3}$ particles and low agglomeration compare to matrix figure (2). The enhancement of electrical and tribological properties of aluminum (Al) alloy by incorporating nano material like $\mathrm{Al}_{2} \mathrm{O}_{3}$ has been rearly investigated. The following experimental results including the electrical conductivity, dielectricity, microstructure, and Wear properties are presented in current section.

\section{Electrical Conductivity and Frequency}

The relationship of $\delta_{a c}$ (electrical conductivity) with frequency $(\mathrm{Hz})$ can be described by the equation (1) (Psarras et al 2003) : 


$$
\delta_{a c}(\omega)=A \omega^{s}
$$

Where $A$ is the proportional factor, $S$ is the exponent factor and $\omega$ is the angular frequency. Applying the above equation to present results for AA7100 and nanocomposite (6wt $\%$ $\mathrm{Al}_{2} \mathrm{O}_{3} / \mathrm{AA} 7100$ ) getting the above constants as illustrated in table (3). The conductivity constant vales $(A, S)$ are obtained by curve fitting the experimental data of conductivity test. The power low equations (Basquen formula) constant which express the conductivity behavior of base metal and nanocomposite. Figure (5) illustrates the relation between electrical conductivity $(\Omega \mathrm{m})^{-1}$ and frequency $(\mathrm{Hz})$. The values of electrical conductivity at various frequencies can be presented in table (4) for AA7100 and $6 \mathrm{wt} \% \mathrm{Al}_{2} \mathrm{O}_{3}$ /AA7100 composite.

It can be notice from the results in table (4) that the electrical conductivity of the base metal AA7100 reduce when the frequency increase. The conductivity recorded $0.816(\Omega \mathrm{m})^{-1}$ at $10^{2} \mathrm{~Hz}$ and then reduced to $0.0455(\Omega \mathrm{m})^{-1}$ at $\left(5^{*} 10^{7}\right) \mathrm{Hz}$ for the base metal AA7100 while the conductivity of composite obtained $13(\Omega \mathrm{m})^{-1}$ to $14.439(\Omega \mathrm{m})^{-1}$ for $10^{2}$ and $5^{*} 10^{7} \mathrm{~Hz}$ respectively. The variation of electrical conductivity $\delta_{a c}$ with frequency for the base metal AA7100 shows that $\delta_{a c}$ reduce with increasing the frequency while for nanocomposite the $\delta_{a c}$ increase when the frequency increase. This finding is consistent with what obtained by (Farah et al 2011). The introduction of $\mathrm{Al}_{2} \mathrm{O}_{3}$ could increase $a c$ conductivity of composite . A higher electrical conductivity would lead to a higher dielectric loss for most nanocomposites. (Fong et al 2016) found that an interface induced polarization between the $\mathrm{SiC}$ ceramic filler and the matrix lead to an increase of $a c$ conductivity. (Chang et al 2018) investigated two nanocomposites systems, namely beta - SiC /PVA and beta - SiC /PVC composites under high frequency. These nanocomposites were fabricated and compared. Linear fitting of experimental data of the relationship between conductivity and frequency . it was found that the conductivity of both nanocomposites increased with increase of frequency.

\section{Dielectric properties}

The experimental results obtained were capacitence ( c ) and by using equation (2). The real dielectric constants $\left(\varepsilon_{\mathrm{r}}\right)$ was calculated as follow (Fares 2011) :

$\varepsilon_{\mathrm{r}}=\frac{c \cdot d}{\varepsilon_{\mathrm{m}} \mathrm{A}}$

where:

$\varepsilon_{\mathrm{r}}$ is a real dielectric constant.

$\mathrm{c}$ is the capacitance ( $\mathrm{F}$ )

$\mathrm{d}$ is the specimen thickness $(\mathrm{m})$

$\mathrm{A}$ is the area of sample ( specimen) $\left(\mathrm{m}^{2}\right)$, and

$\varepsilon_{\circ}$ is the permittivity in vacum $\left(8.854 * 10^{-12} \mathrm{c} / \mathrm{Nm}^{2}\right)$

The dissipation factor $(\tan \delta)$ can be measured from the LCR appratus and the imaginary dielectric $\left(\varepsilon^{\prime \prime}\right)$ constant was calculated from equation (3) (Fares 2011).

$\tan \delta=\frac{\varepsilon r}{\varepsilon^{*}}$ or $\frac{\varepsilon^{*}}{\varepsilon^{*}}$

Figures (6 to 9) show the variation of $\varepsilon^{\prime}$ and $\varepsilon^{\prime \prime}$ with frequency for both base metal and composite.It is clear from Figures (6-9) that at low frequency the dielectricity properties are high for both metal matrix and composite, also the above Figures show that the $80 \mathrm{~Hz}$ frequency produces the highest dielectric properties but the composite exhibits more than the metal matrix. The dissipation factor $(\tan \delta)$ is related to the capacitance of material. A material 
having low capacitance shows high dissipation factor $(\tan \delta)$ and vice versa. This finding is agreed well with the finding of (Ayu et al 2018). Figures (10a, b) show the frequency against $(\tan \delta)$ for metal matrix and composite. The dissipation factor $(\tan \delta)$ is related to the quality factor which is related to the energy lost in the capacitor and the energy lost is generally heat. It is know that porosity affects the physical properties like dielectric constants. A solid material has the dissipation factor $(\tan \delta$ ) close to zero (Penn et al 1997). But if the material is porous, then the above factor has an important value. Two factors are effected conductivity which are ions motions and interfacial polarization. Ions motions is contributed at high frequency while interfacial polarization is contributed at low frequency. The rapid increase of conductivity with increasing frequency greater than $10^{4} \mathrm{~Hz}$ referred to the electronic polarization (Keith \&John 2004).

\section{Wear test results analysis}

A pin-on-disc test device was employed to carry out all the wear experiments. The wear specimens were cleaned with acetone prior to test, and then each sample was weighed by a digital balance having an accuracy of $( \pm) 0.0002 \mathrm{gm}$. Mounting the specimen on the holder of pin, track distance (diameter $10 \mathrm{~cm}$, load $20 \mathrm{~N}$ and the interval time was 10 minute and the total time was 50 minute. All the wear experiments were done at room temperature (RT). The rpm was taken to be $300 \mathrm{rpm}$ giving sliding speed of $1.57 \mathrm{~m} / \mathrm{sec}$ and distance of $942 \mathrm{~m}$ for each run. Table (5) gives the results of weight loss carried out on AA7100 alloy and $6 \mathrm{wt} \% \mathrm{Al}_{2} \mathrm{O}_{3}$ composite. Table (5) shows the results of wear resistance for total time of 50 minutes. Cumulative wear tests were done for $50 \mathrm{~min}$ total time and the experimental results are tabulated in table (6).Figure (11) shows the wear rate against the sliding distance for both base metal and composite. It is clear that the wear rate reduce after addition the nano particles $\mathrm{Al}_{2} \mathrm{O}_{3}$ compared to the matrix (AA7100). The main reason is the incorporation of hard particles of $\mathrm{Al}_{2} \mathrm{O}_{3}$ in to the matrix AA7100 leading to improve the wear resistance. The improvement in the wear resistance (decrease in wear rate) in percentage of $6 \mathrm{wt} \% \mathrm{Al}_{2} \mathrm{O}_{3}$ can be attributed to the enhancement in the mechanical and hardness of composite, see table (2). Also the increasing in sliding distance leads to reducing trend in wear rate. This conclusion was in good agreement with that concluded by (Kheder 2011).

\section{CONCLUSIONS}

In this work, the microstructure analysis, electrical conductivity, dielectric constants, dissipation factor $(\tan \delta)$ and tribological properties of aluminum alloy AA7100 metal matrix with $6 \omega t \% \mathrm{Al}_{2} \mathrm{O}_{3}$ reinforcement were examined and has led to following conclusion:

1- The nanocomposite containing $\mathrm{AA} 7100$ with $6 \mathrm{wt} \% \mathrm{Al}_{2} \mathrm{O}_{3}$ metal matrix composite using stir casting method was successfully fabricated.

2- The optical microstructure of composite showed fairly uniform distribution and the $\mathrm{Al}_{2} \mathrm{O}_{3}$ particles were separated at inter- dendritic grains.

3- The variation of electrical conductivity $(\delta \mathrm{ac})$ with frequency for metal matrix showed that the $(\delta$ ac) reduce with increasing frequency while for composite the $(\delta$ ac) increase with increasing frequency.

4- The components of relative permittivity for metal matrix and composite decrease with increasing frequency and at low frequency range $\left(10^{2}-10^{4}\right) \mathrm{Hz}$ the nanocomposite has a higher relative permittivity compared to metal matrix.

5- It was observed that the wear loss and wear rate for nanocomposites are lower than that of metal matrix. 
Table (1) chemical analysis of AA7100

\begin{tabular}{|c|c|c|c|}
\hline $\begin{array}{c}\text { Chemical } \\
\text { composition }\end{array}$ & $\begin{array}{c}\text { Element } \\
\text { wt\% of } \\
\mathrm{Al} 1700\end{array}$ & $\begin{array}{c}\text { Chemical } \\
\text { composition }\end{array}$ & $\begin{array}{c}\text { Element wt\% } \\
\text { of Al7100 }\end{array}$ \\
\hline $\mathrm{Mg}$ & 0.155 & $\mathrm{~Pb}$ & 1.50 \\
\hline $\mathrm{Cu}$ & 0.0200 & $\mathrm{Ca}$ & 0.441 \\
\hline $\mathrm{Mn}$ & 93.4194 & $\mathrm{~V}$ & 1.0 \\
\hline $\mathrm{Fe}$ & 0.0121 & $\mathrm{Cr}$ & 2.0 \\
\hline $\mathrm{Zn}$ & 0.0402 & Others & 0.0404 \\
\hline $\mathrm{Ti}$ & 0.135 & $\mathrm{Sn}$ & 0.764 \\
\hline $\mathrm{Si}$ & 0.114 & $\mathrm{Al}$ (Balnce) & 0.391 \\
\hline
\end{tabular}

Table (2) mechanical properties of base metal, composite and reinforcement material

\begin{tabular}{|c|c|c|c|c|}
\hline Material & $\sigma u\left(\mathrm{MP}_{\mathrm{a}}\right)$ & $\sigma \mathrm{y}\left(\mathrm{MP}_{\mathrm{a}}\right)$ & hardness & $\epsilon \%$ \\
\hline $\mathrm{AA} 7100$ & 115 & 82 & 74 & 16.72 \\
\hline $\mathrm{AA} 7100 / 6 w \mathrm{wt} \% \mathrm{Al}_{2} \mathrm{O}_{3}$ & 138 & 102 & 79 & 15.6 \\
\hline $\mathrm{Al}_{2} \mathrm{O}_{3}$ (Batool 2018) & $\begin{array}{c}2100 \\
\text { compression }\end{array}$ & 1060 & 1175 & --- \\
\hline $\begin{array}{c}\text { Improvement } \\
\text { percentage }\end{array}$ & $20 \%$ & $27.5 \%$ & $6.7 \%$ & $6.69 \%$ \\
\hline
\end{tabular}

Note that: mechanical properties of AA7100 are done according to (ASTMA370).

Table (3): conductivity constant value and conductivity equation

\begin{tabular}{|c|c|c|c|}
\hline material & $A$ & $S$ & Frequency dependence conductivity equation \\
\hline $\mathrm{AA} 7100$ & 2.25 & 0.22 & $\delta_{a c}(\omega)=2.25 \omega^{-0.22}$ \\
\hline $\begin{array}{c}\text { AA7100/6wt } \% \mathrm{Al}_{2} \mathrm{O}_{3} \\
\text { composite }\end{array}$ & 12.53 & 0.008 & $\delta_{a c}(\omega)=12.53 \omega^{0.008}$ \\
\hline
\end{tabular}

Table (4): electrical conductivity values at different frequency for base metal and composite

\begin{tabular}{|c|c|c|c|c|c|c|c|}
\hline Freq. $(\mathrm{Hz})$ & $10^{2}$ & $10^{3}$ & $10^{4}$ & $10^{5}$ & $10^{6}$ & $10^{7}$ & $5^{*} 10^{7}$ \\
\hline \multicolumn{8}{|c|}{ electrical Conductivity $(\Omega m)^{-1}$} \\
\hline base metal & 0.816 & 0.492 & 0.296 & 0.178 & 0.107 & 0.064 & 0.0455 \\
\hline composite & 13 & 13.24 & 13.488 & 13.738 & 13.99 & 14.25 & 14.439 \\
\hline
\end{tabular}

Table (5): Weight loss before and after the addition of $\mathrm{Al}_{2} \mathrm{O}_{3}$

\begin{tabular}{|c|c|c|}
\hline \multirow{2}{*}{ Weight loss gm } & AA7100 & Composite $6 \mathrm{wt} \% \mathrm{Al}_{2} \mathrm{O}_{3}$ \\
\cline { 2 - 3 } & 0.65 & 0.32 \\
\hline Wear rate $\mathrm{mm}^{3} / \mathrm{N} . \mathrm{m} * 10^{-3}$ & 12.6 & 6.217 \\
\hline
\end{tabular}


Table (6) cumulative wear rate results for base metal and composite

\begin{tabular}{|c|c|c|c|c|c|}
\hline Time min. & \multirow{2}{*}{$\begin{array}{c}\text { Sliding } \\
\text { distance } \mathrm{m}\end{array}$} & \multicolumn{2}{|c|}{$\begin{array}{c}\text { Cumulative weight loss } \\
(\mathrm{gm})\end{array}$} & \multicolumn{2}{c|}{$\begin{array}{c}\text { Cumulative wear rate } \\
\mathrm{mm}^{3} / \mathrm{N} . \mathrm{m} * 10^{-3}\end{array}$} \\
\cline { 3 - 6 } & & AA7100 & Composite & AA7100 & Composite \\
\hline 10 & 942 & 0.65 & 0.32 & 12.6 & 6.217 \\
\hline 20 & 1884 & 0.82 & 0.51 & 7.96 & 4.95 \\
\hline 30 & 2826 & 0.96 & 0.64 & 6.217 & 4.144 \\
\hline 40 & 3768 & 1.25 & 0.74 & 6.071 & 3.594 \\
\hline 50 & 4710 & 1.42 & 0.81 & 5.517 & 3.147 \\
\hline
\end{tabular}

Note that the density of aluminum was taken to be $0.002732 \mathrm{gm} / \mathrm{mm}^{3}$ taken from (Robert 2004).

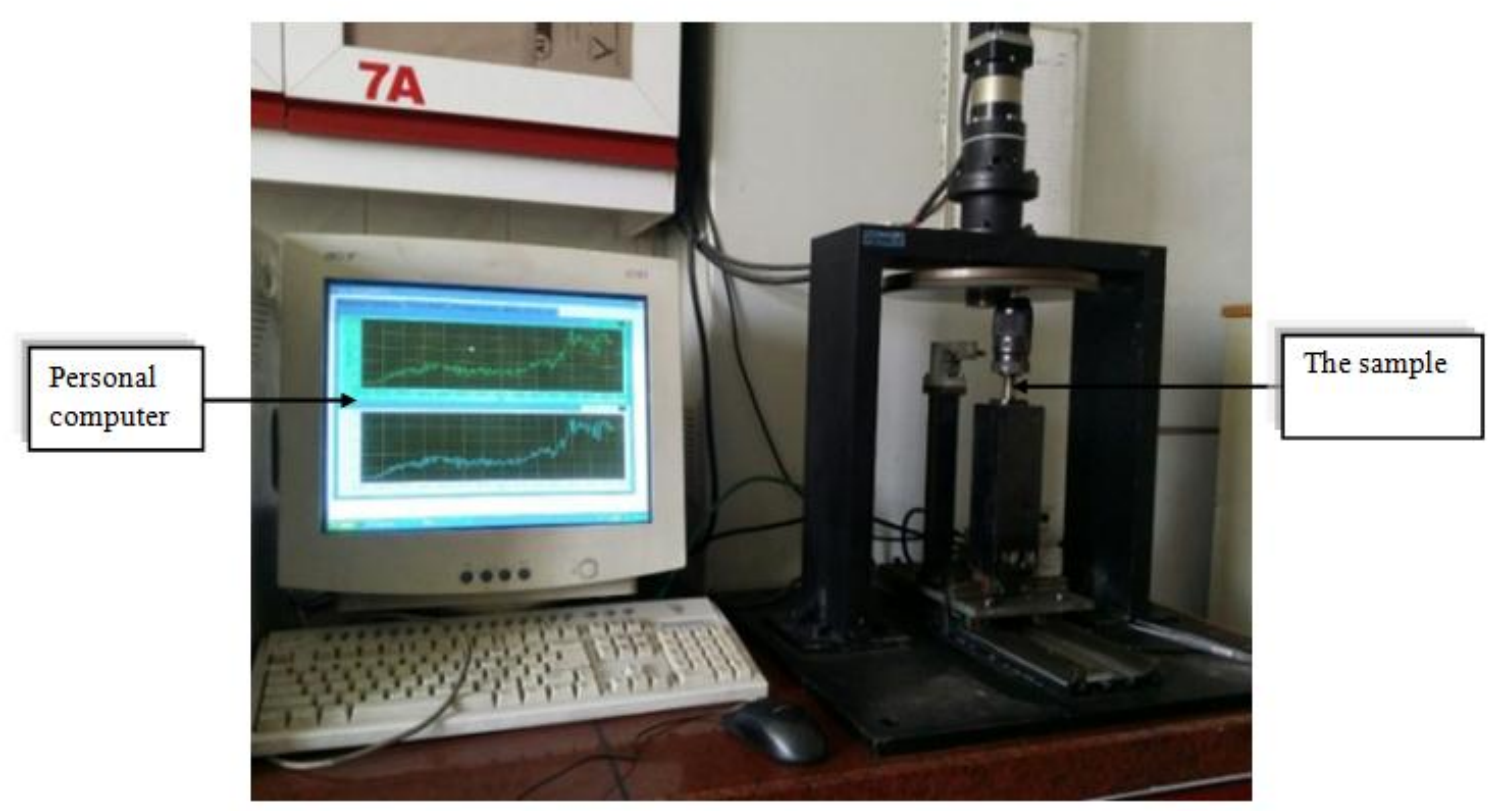

Figure (1): Computerized pin -on -disc device 


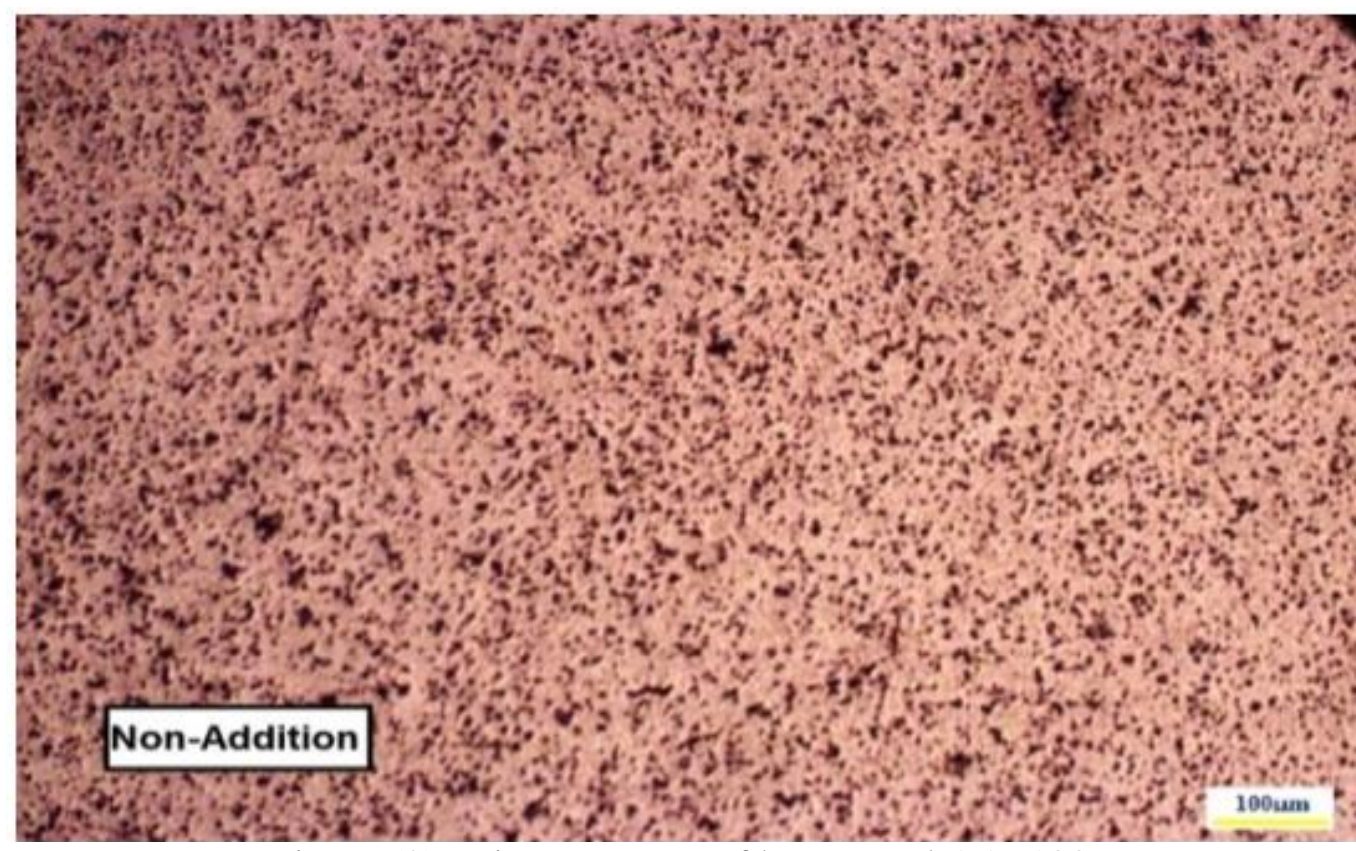

Figure (2): microstructure of base metal AA7100

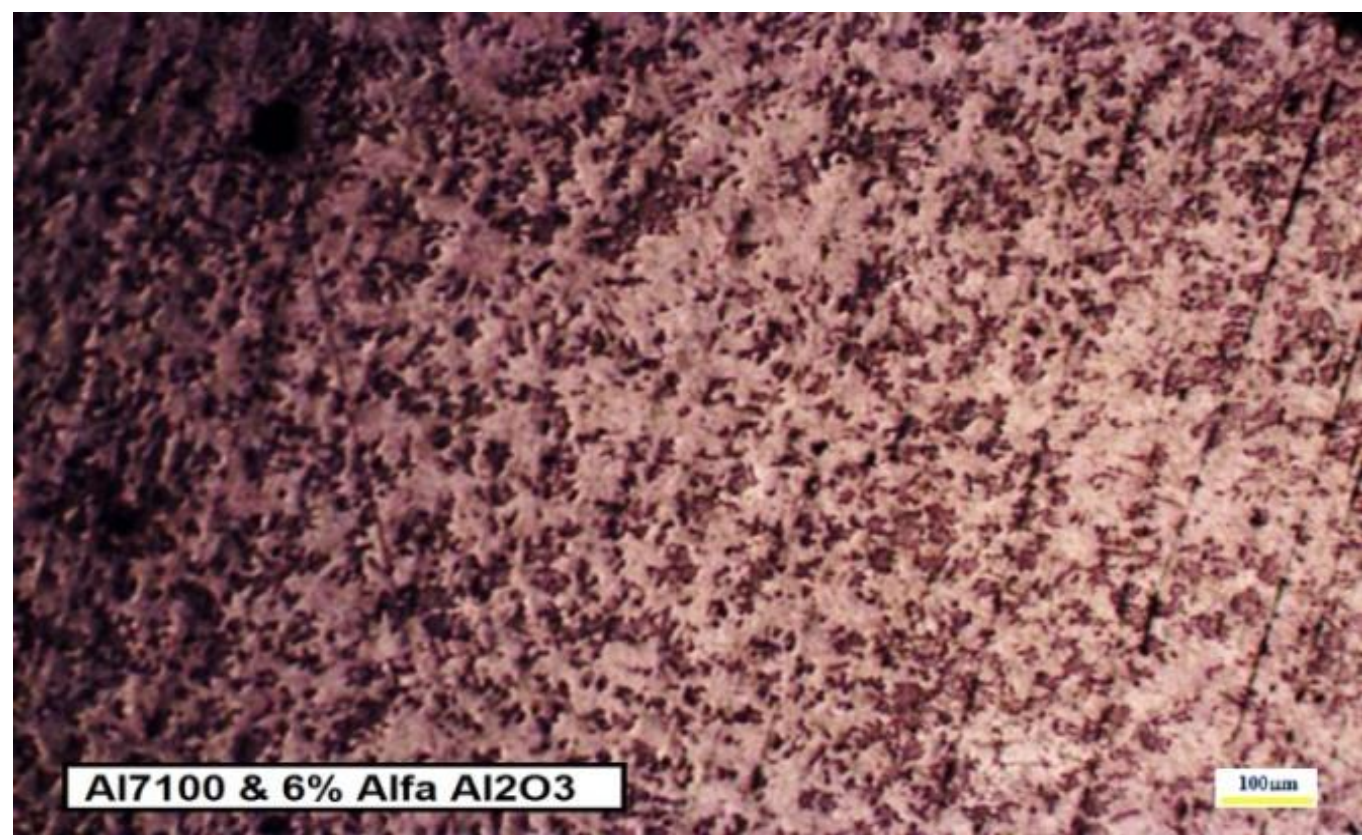

Figure (3):microstructure of nanocomposite

$\left(\mathrm{AA} 7100 / 6 \mathrm{wt} \% \mathrm{Al}_{2} \mathrm{O}_{3}\right)$ 


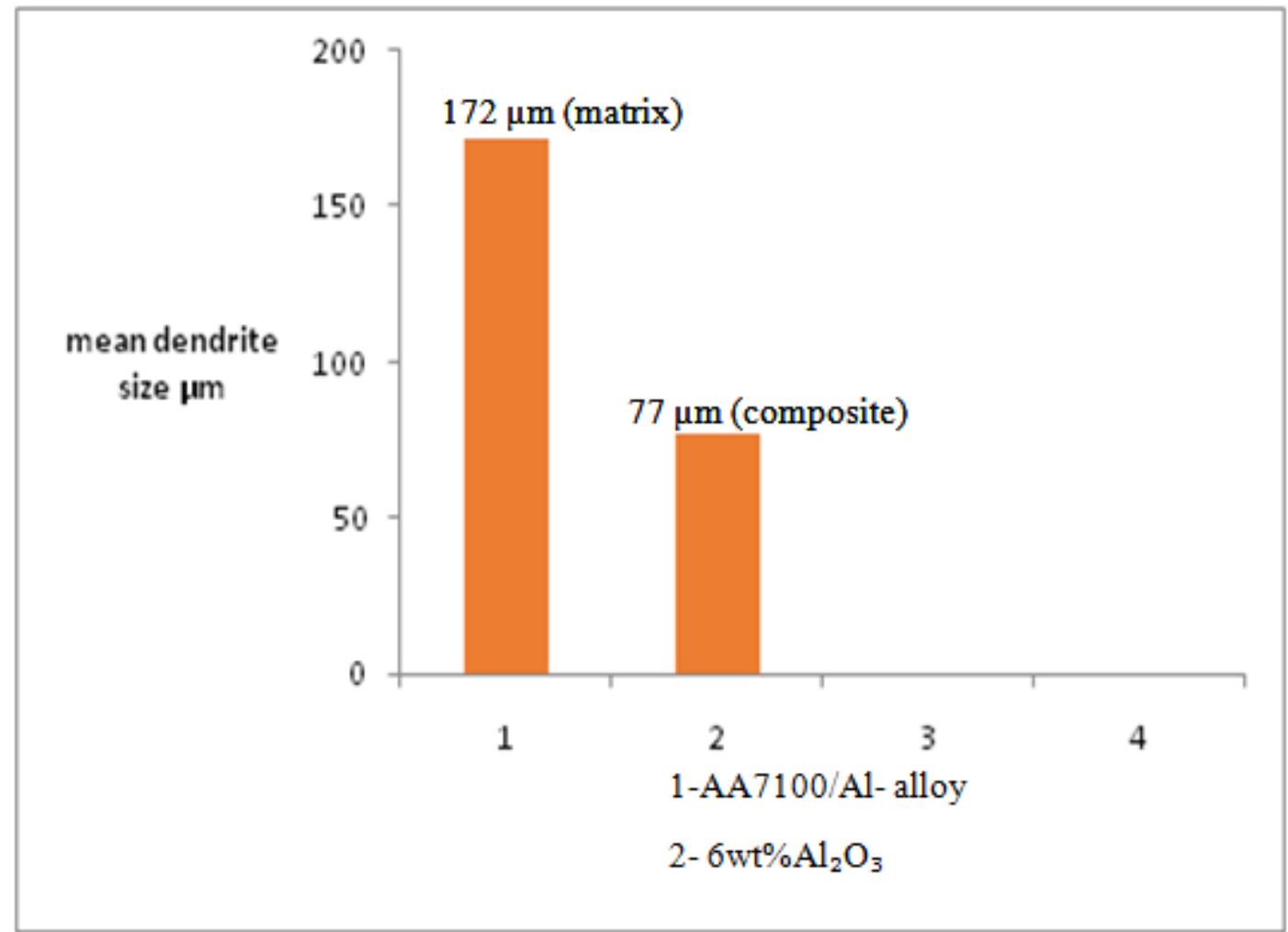

Figure (4): Comparison of mean dendrite size for Al- alloy and $\mathrm{AA} 7100 / 6 \mathrm{wt} \mathrm{Al}_{2} \mathrm{O}_{3}$ composite

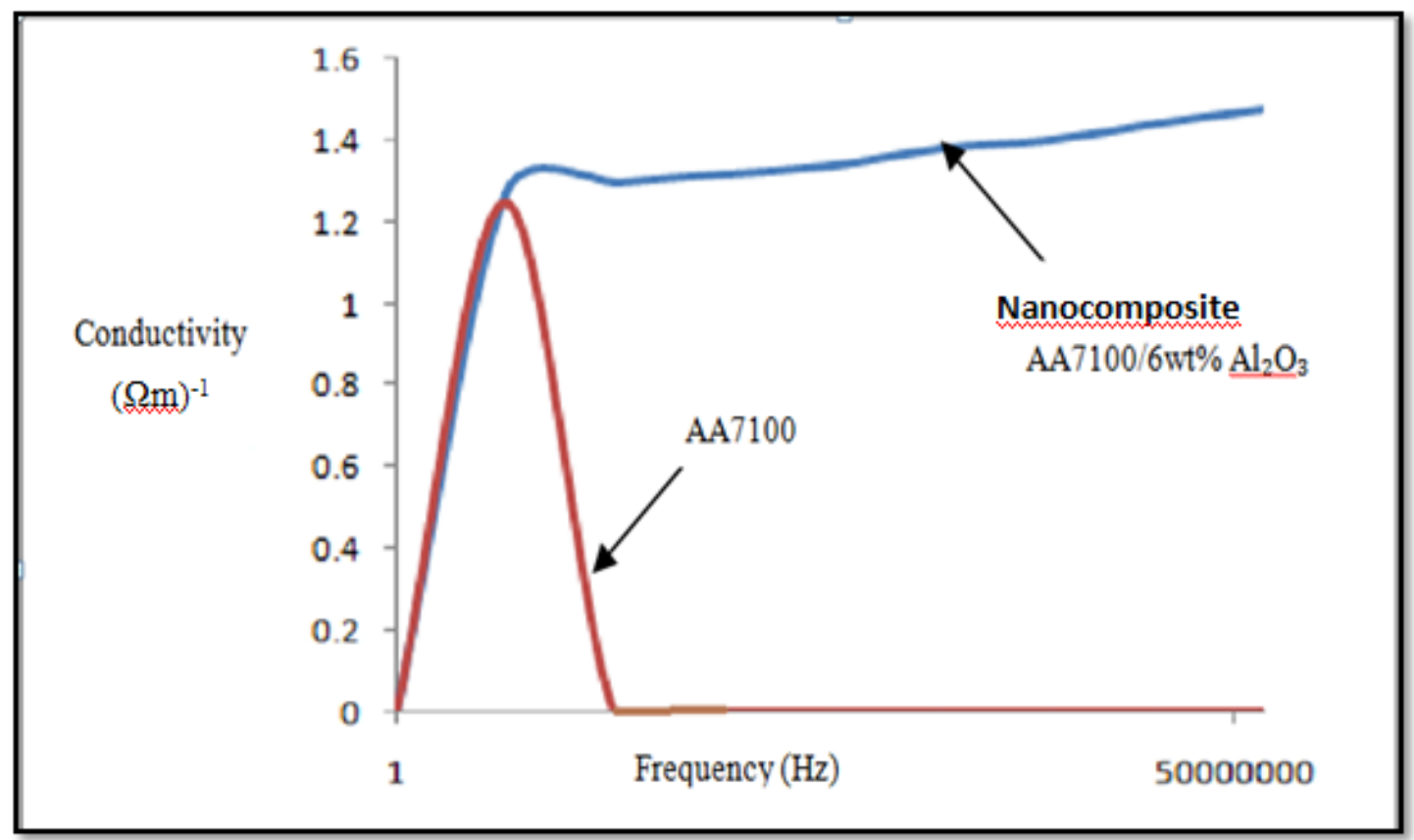

Figure (5): the relation between conductivity $(\Omega \mathrm{m})^{-1}$ and frequency $(\mathrm{Hz})$ 


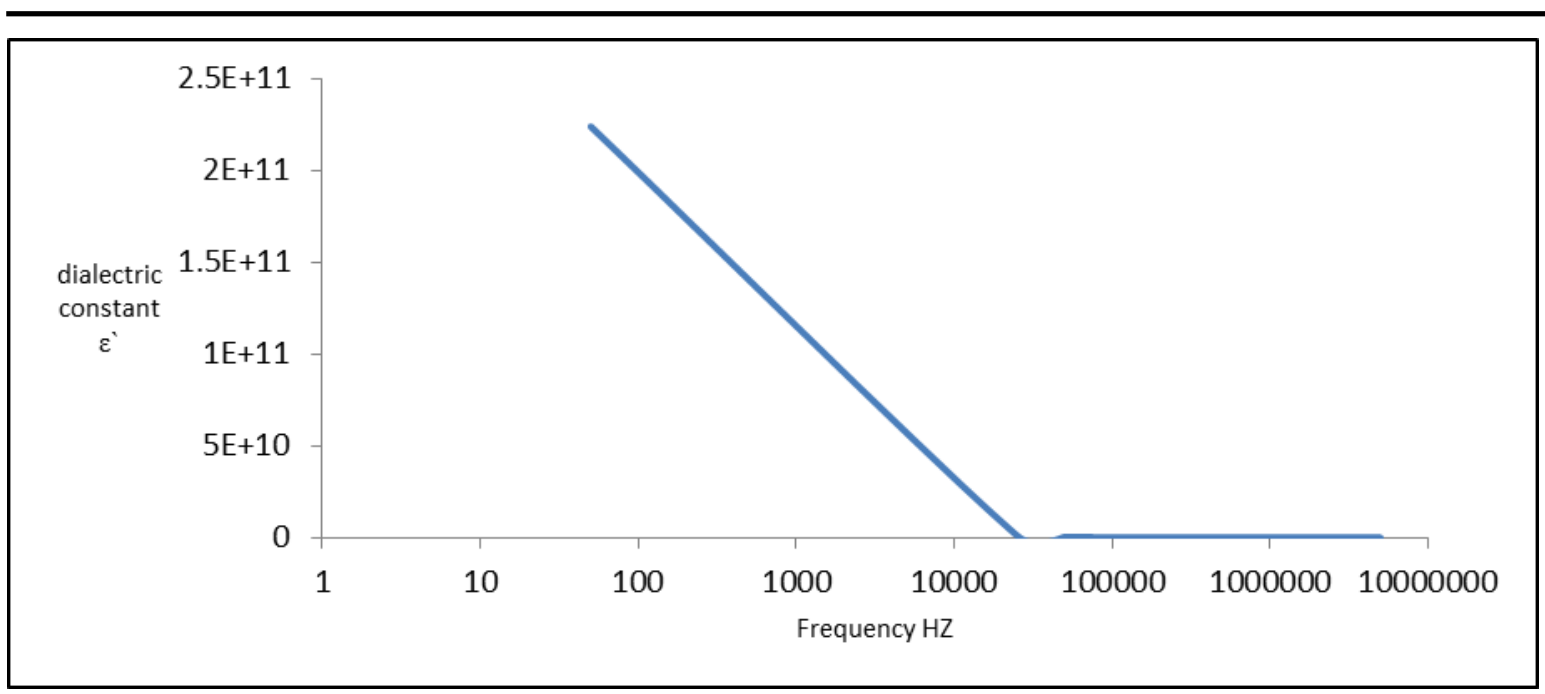

Figure (6): The effect of frequency on real dielectric constants ( $\left.\varepsilon^{\prime}\right)$ for metal matrix AA7100

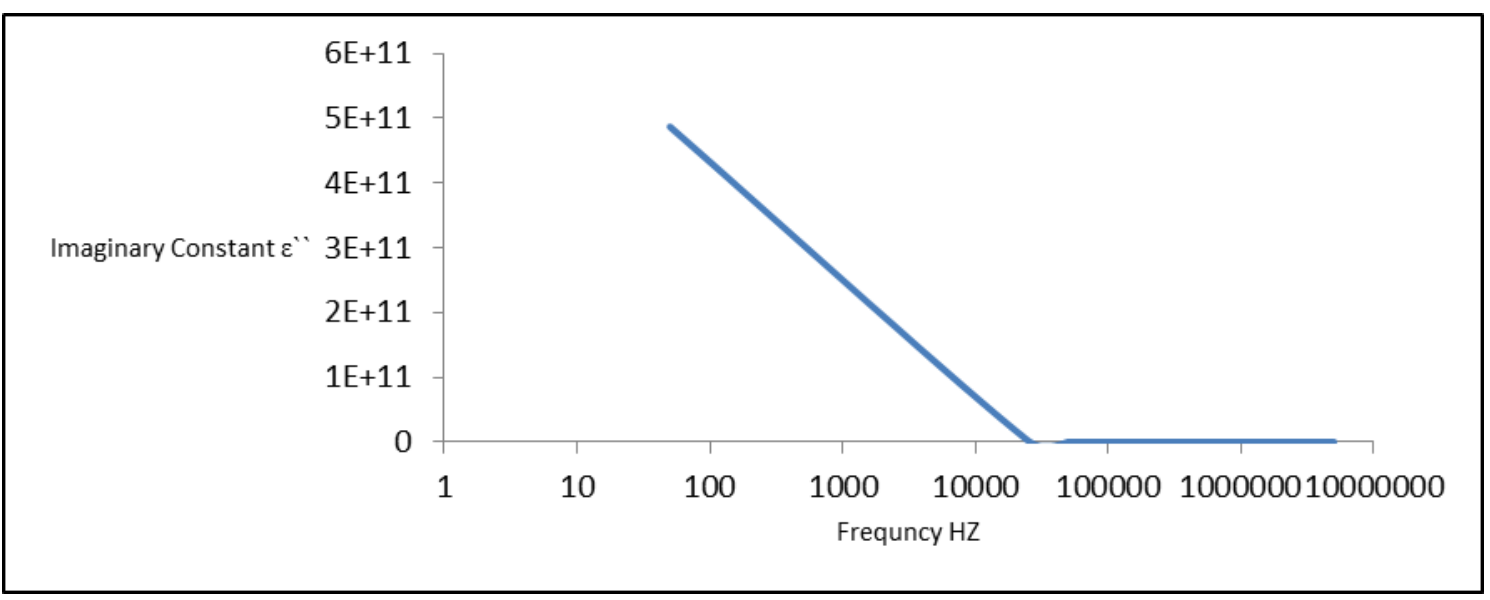

Figure (7): The effect of frequency on imaginary dielectric constants $\left(\varepsilon^{\prime \prime}\right)$ for metal matrix AA7100

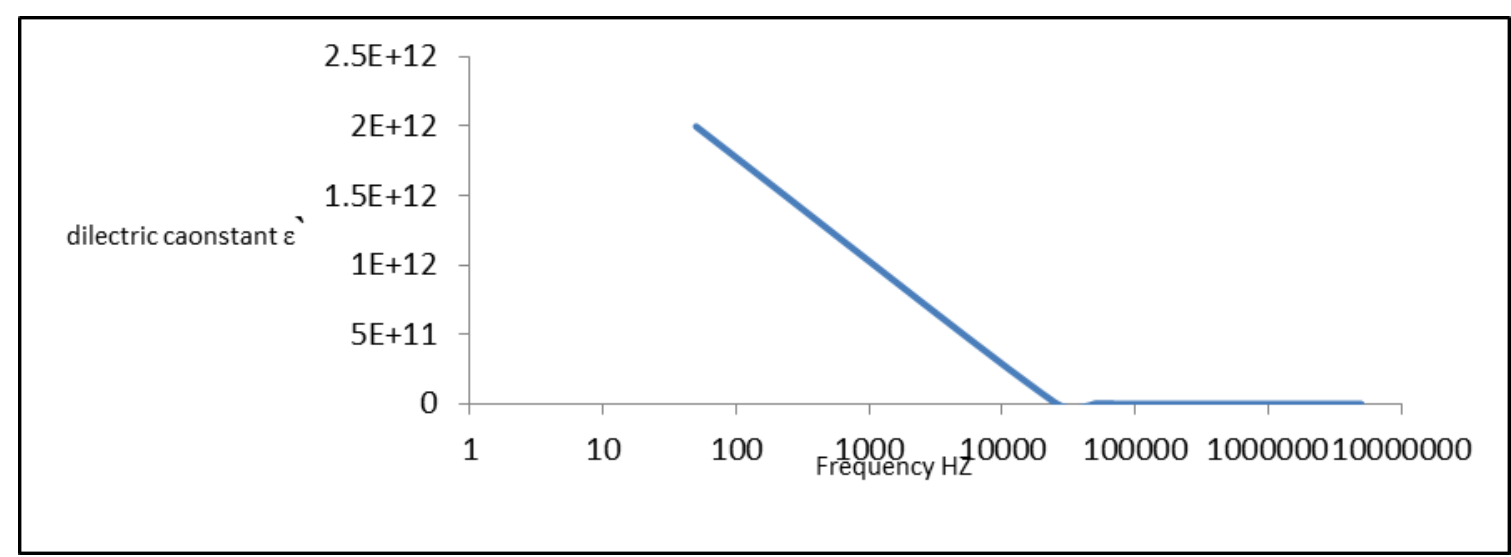

Figure (8): The effect of frequency on real dielectric constants $\left(\varepsilon^{\prime}\right)$ for composite $6 \mathrm{wt} \%$ $\mathrm{Al}_{2} \mathrm{O}_{3} / \mathrm{AA} 7100$ 


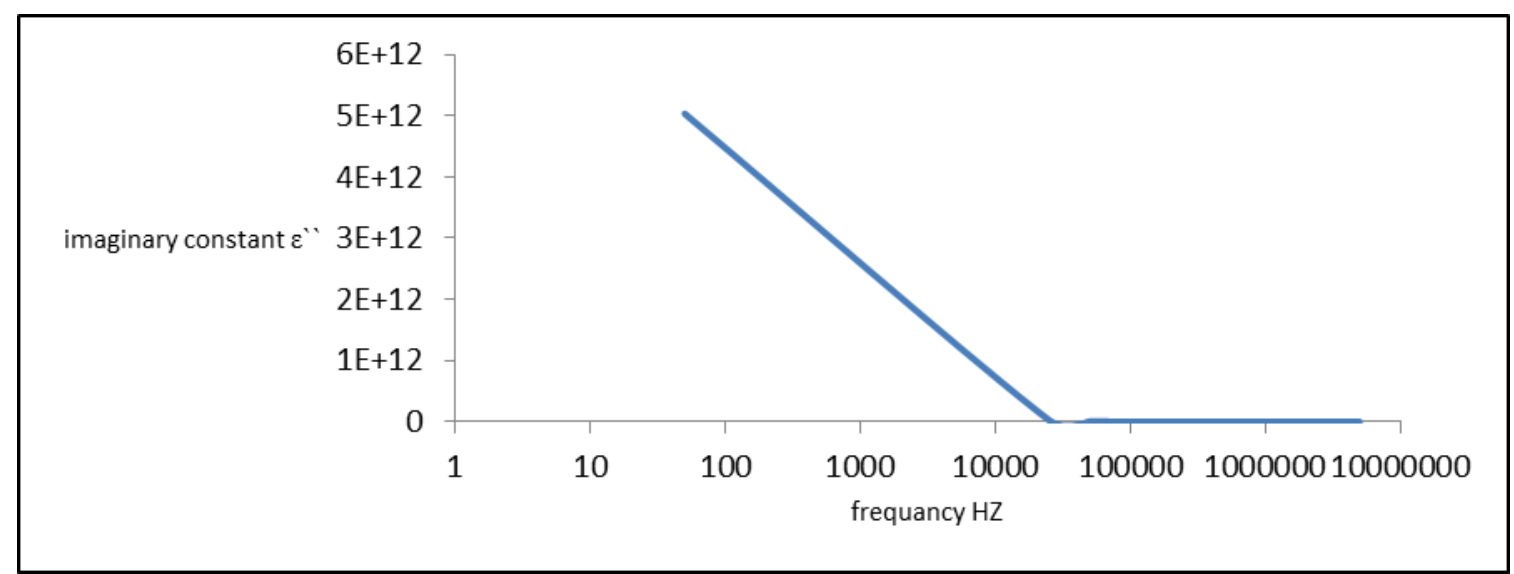

Figure (9): The effect of frequency on imaginary dielectric constants ( $\left.\varepsilon^{\prime \prime}\right)$ for composite $6 \mathrm{wt}$ $\% \mathrm{Al}_{2} \mathrm{O}_{3} / \mathrm{AA} 7100$

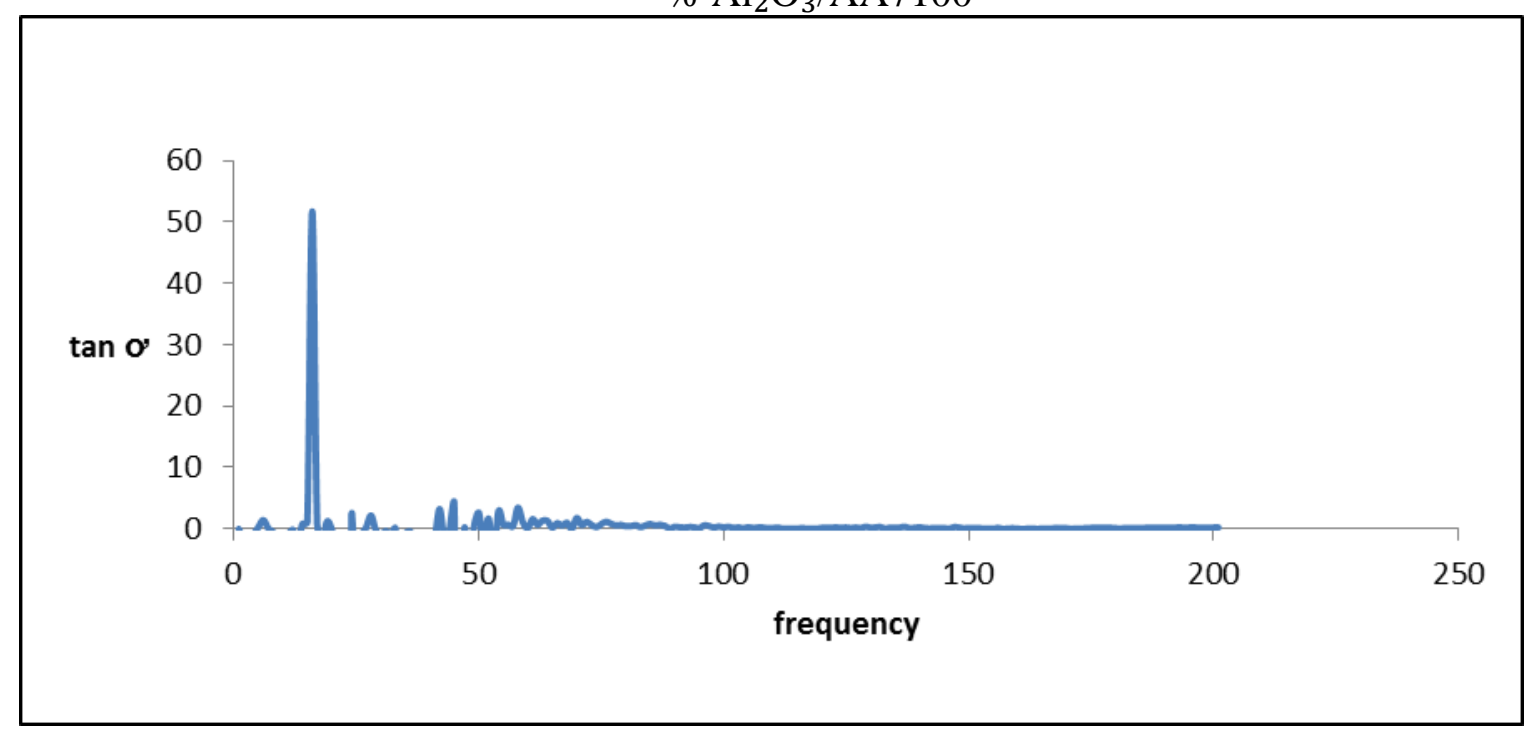

(a)

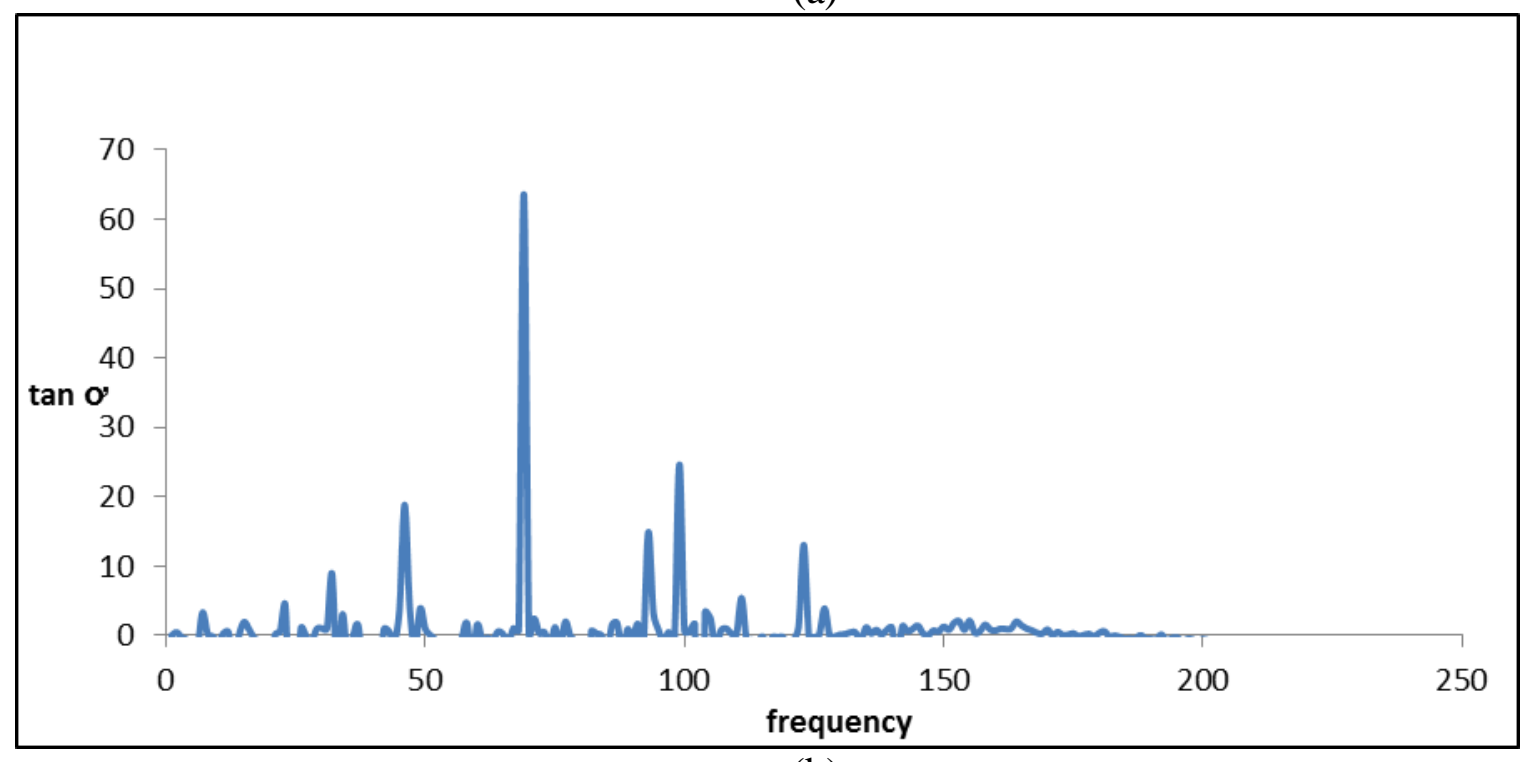

(b)

Figure (10): (a) the effect of frequency on $(\tan \delta)$ for metal matrix

(b) the effect of frequency on $(\tan \delta)$ for composite 


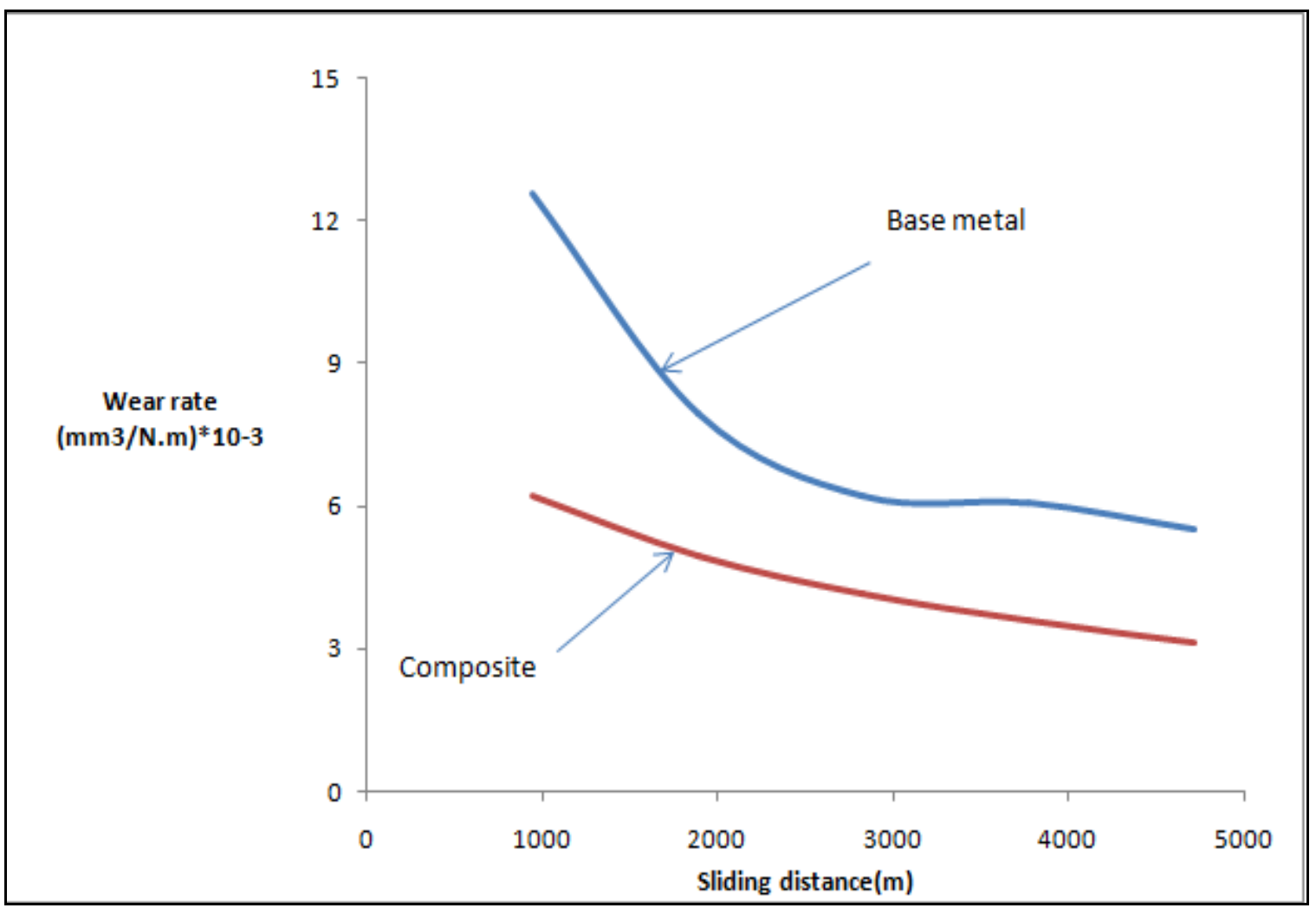

Figure: (11) wear rate against sliding distance

\section{References}

ALalkawi H.J.M , Aseel A.A , Magda K.A., "comparison between mechanical properties , microstructure and electrical conductivity of AA2024 doped with various amount of aluminum and Zirconium oxide", Acceptable for publication in Journal of engineering and applied science, Medwell Journals, 2018.

ALalkawi H.J.M., Ghada Adel Aziz, Hussain A. ALjwad, "Preparations of new aluminum matrix composite reinforced with hybrid nano reinforcements $\mathrm{Fe}_{2} \mathrm{O}_{3}$ and $\mathrm{Al}_{2} \mathrm{O}_{3}$ via (P/M) route", Acceptable for publication in Journal of engineering and applied science, Medwell Journals, 2018.

Ayu A.M., Markus D.,Nandang M.,Nasikhudin, Risa S., "The effect of nano Zno morphology on structure dielectric constant, and dissipation factor of CA-nanoZno/Ito films", Neutrino journan, vol. 10,No. 2, pp.65-74, 2018 .

Batool K. Hmood, "Mechanical, electrical and microstructure properties studies of AA6001/ $\mathrm{Al}_{2} \mathrm{O}_{3}$ Nanocomposites using stir casting method", Master thesis, electromechanical engineering department, university of technology, Baghdad, Iraq, 2018.

Chen X.H., Yan H., "Effect of nano particle $\mathrm{Al}_{2} \mathrm{O}_{3}$ addition on microstructure and mechanical properties of 7075 Alloy", International Journal of cast metals research, vol.28,No.6, 2015. 
Cheng P., Yefeng F., Jiabing H, "Enhancing high - frequency dielectric properties of Beta-SiC filled nanocomposites from synergy between Percolation and polarization",materials, 11, 1699 ,2018.

Dinesh K.K, Geeta A., Rajesh P. , "Influence of ultrasonic assisted stir casting on mechanical properties of Al6061- Nano $\mathrm{Al}_{2} \mathrm{O}_{3}$ composites" , material today: proceeding 2, pp.3017-3026, 2015 .

Farah T.M.N. , Ekram A.A. , Dunia K. AL-Nasrawy , "A.C conductivity and dielectric properties of Epoxy - $\mathrm{TiO}_{2}$ Nano composites". Iraqi J. of physics, Vol.9, No. 14, pp 102-108, 2011.

Fares S., "Frequency dependence of the electrical conductivity and dielectric constant of polycarbonate (Makrofol-E) film under the effects of $\mathrm{y}$-Radiation" ,American Journal of materials science vol.1,pp.52-56, 2011.

Feng Y., Gong H.,Xie Y.,Wei X, Zhang Z., "significantly elevated dielectric permittivity of Sibased semiconductor/ polymer", Journal of Physics D Applied Physics vol.49,No.7, 2016.

Ferreira, E . BoyraKtar, I. Miskiioglu, M.H Rober, "New magnetic aluminum matrix composites (AL-Zn-Si) reinforced with nano magnetic Fe3O4 for aeronautical application", Advanced in materials and processing technologies, 2018.

Ferreira, E. Boyrakta, M.H. Robert. "Magnetic and electrical properties of aluminum matrix composite reinforced with magnetic Nano iron oxide (Fe3O4)", Advances in materials and processing technologies - on line, 2016.

IsIaK S. Kir D. , Buytoz S. , "Effect of sintering temperature on electrical and microstructure properties of hot pressed $\mathrm{Cu}$-TiC composites”, Science of sintering, 46, 15-21, 2014.

J.Keith N.,John C.F., "Internal charge behavior of nanocomposites", nanotechnology journal, vol.15,No.5,2004.

Kheder, "String thing of aluminum by $\mathrm{SiC}, \mathrm{AL}_{2} \mathrm{O}_{3}$ and $\mathrm{Mgo}$ ", Jordan Journal of mechanical and Industrial Engineer, ISSN 1995-6665, 533-541, 2011.

Nalluswamy, A. Karthinkeyan, "Analysis of wear resistance, cracks and hardness of metal matrix composites with Sic additives and $\mathrm{Al}_{2} \mathrm{O}_{3}$ as reinforcement", Indian J. of science and Technology, Vol. 9 No. 35, 2016.

Penn S.J., Alford N.M. , Templeton A, Wang X, Xu, M, Reece M., "Effect of porosity and grain size on the Microwave dielectric properties of sintered Aluminum", Journal of the American ceramic Society, vol. 80, Issu.(7),pp. 1885-1888, 1997 .

Psarras G.C, Manolakaki E.,Tsangaris G.M. , "Dielectric dispersion and a.c conductivity in Iron particales", Applied science and manufacturing journal, vol. 34,Issu. 12, pp.1187-1198, 2003.

Rajasckhar S. Hariprosada R-Y, "investigation on wear rate of AL16061/ Sic/Zr hybrid metal matrix composite", IJERMCE, Vol. 2, issue 9, 2017. 
Ramanchandra M. Abhishek A., sideshwar p. Blaarthiv, "Hardness and wear resistance of $\mathrm{ZrO}_{2}$ nanoparticle reinforced AL nanocomposites produced by powder metallurgy", 2n internal conference on nano materials and technologies, procedia materials science journal vol. 10,pp.212-219, 2015.

Robert L.Mott . "Machine elements in mechanical design”, pearson prentice hall ,2004.

Subhash K., Ritu M., Ajay D., ShiKha A., "Electrical conductivity of cadmium oxide nano particles embedded polyaniline nanocomposites", Advances in applied science research, 2 (4), 401-406. 2011. 